\title{
Correction
}

\section{Correction: Differential Peripheral Blood Gene Expression Profile Based on Her2 Expression on Primary Tumors of Breast Cancer Patients}

\section{The PLOS ONE Staff}

The second affiliation for the third author is not indicated. Loredana Balacescu is affiliated with: 1 Department of Functional Genomics and Experimental Pathology, The Oncology Institute I. Chiricuta, Cluj-Napoca, Romania, and 2 Research Center for Functional Genomics, Biomedicine and Translational Medicine, Iuliu Hatieganu University of Medicine and Pharmacy, ClujNapoca, Romania.

\section{Reference}

1. Tudoran O, Virtic O, Balacescu L, Pop L, Dragla F, et al. (2014) Differential Peripheral Blood Gene Expression Profile Based on Her2 Expression on Primary Tumors of Breast Cancer Patients. PLoS ONE 9(7): e102764. doi:10.1371/ journal.pone. 0102764
Citation: The PLOS ONE Staff (2014) Correction: Differential Peripheral Blood Gene Expression Profile Based on Her2 Expression on Primary Tumors of Breast Cancer Patients. PLoS ONE 9(10): e110962. doi:10.1371/journal.pone.0110962

Published October 13, 2014

Copyright: (๑) 2014 The PLOS ONE Staff. This is an open-access article distributed under the terms of the Creative Commons Attribution License, which permits unrestricted use, distribution, and reproduction in any medium, provided the original author and source are credited. 